\title{
Effect of thermal treatment on phenolic and antioxidant content of fresh bael juice
}

\section{Ipsita Banerjee and Uma Ghosh}

Received : 24.04.2018; Revised : 03.08.2018; Accepted : 20.08.2018

See end of the Paper for authors' affiliation

Correspondence to :

Uma Ghosh

Department of Food

Technology and Biochemical

Engineering, Jadavpur

University, Kolkata (W.B.)

India

Email :

ughoshftbe@yahoo.co.in
ABSTRACT : Bael (Aegla marmelos) is one of the important fruit in India and bael juice is most important source of antioxidants. The loss of phenolic compound and antioxidant content over the temperature range of $55-85^{\circ} \mathrm{C}$ was studied. Degradation kinetics was best fitted by first order reaction kinetic model for both phenolic compound and antioxidants. Arhenius and Erying polany models had been used to determine the temperature dependent degradation. Following the Arhenius model, the activation energy for the phenolic compound and antioxidants were 18.52 and $45.08 \mathrm{KJ} \mathrm{mol}^{-1}$, respectively. The retention of phenolic compound and antioxidants of bael juice treated at $55^{\circ} \mathrm{C}$ for 90 min was more than 61 and 68 per cent, respectively as that of fresh bael juice.

- KEY WORDS : Phenolic compound, Antioxidant, Degradation kinetic, Arhenius, Erying-Polany, Activation energy

- HOW TO CITE THIS PAPER : Banerjee, Ipsita and Ghosh, Uma (2018). Effect of thermal treatment on phenolic and antioxidant content of fresh bael juice. Internat. J. Agric. Engg., 11(2) : 282-288, DOI: 10.15740/HAS/IJAE/11.2/282-288. Copyright@ 2018: Hind Agri-Horticultural Society. 